\title{
Exploring Indigenous Approaches to Conflict Resolution: The Case of the Bawku Conflict in Ghana
}

\author{
Kaderi Noagah Bukari \\ PhD Candidate at the Zentrum Fur Entwicklungsforschung, Center for Development \\ Research (ZEF), University of Bonn \\ Email: bukarinoagah@yahoo.com
}

Accepted: May 23, 2013 Published: June 25, 2013

Doi:10.5296/jsr.v4i2.3707

URL: http://dx.doi.org/10.5296/jsr.v4i2.3707

\begin{abstract}
Ghana has a number of ethnic conflicts, most of which are protracted mainly because of the type and nature of conflict resolution mechanisms that are used in finding solutions to them. Many of the solutions to these conflicts often fail to adopt home-based mechanisms (indigenous) in resolving them since most of our conflicts have traditional underpinnings. Many resolution measures have been used and continued to be used in bringing lasting peace to Bawku, but the area is yet to have lasting peace. This paper is an empirical study which uses the views of traditional actors to examine how indigenous mechanisms in the Bawku Traditional Area can be explored in resolving the ethnic conflict in the area. The study reveals that indigenous methods of conflict resolution in the Bawku Traditional Area can be effective in resolving the conflict through an integration of both Kusasis and Mamprusis indigenous approaches.
\end{abstract}

Keywords: conflict, Ghana, Bawku, peace, conflict resolution, indigenous approaches.

\section{Introduction}

The biggest challenge today confronting humans is not about the occurrence of conflict per se, but how these conflicts are fully resolved whenever they occur to prevent them from further escalating. Conflict will continue to exist with humanity since they like death, are inevitable. The inevitability of conflicts, however, becomes pathological to society depending on the type and nature of the resolution methods used. Many a time, the intervention mechanisms to a conflict right from its onset can be problematic and therefore can be a source of conflict itself. Conflicts often occur within a certain political, economic, social and cultural milieu. Today, many of the conflicts that occur or what Kaldor (2007) called 'new wars' are more internal, non- conversational and culture-sensitive (Boege, 2006). Many of these 'new wars' need intervention mechanisms that are culturally-based and relate to their environment of occurrence. 
Many of the people of Africa in the past have lived together peacefully and had their own ways of settling their disputes before the colonialists arrived. In their attempts to set up administrative structures to make their governance easier, many ethnic groups were forced into cohesive structures by the colonists destroying many of the roots of traditional structures including mechanisms of conflict resolution (Awedoba, 2009). These forced administrative structures resulted in many of the lingering conflicts in many parts of Africa today (Awedoba, 2009).

Thus, this has led to a spate of new and different conflicts in Africa with varied causes. These conflicts include predominantly, ethnic conflicts between rival ethnic groups, internal conflicts, conflicts over succession and power struggles within the state and conflicts over the control of state resources (Idowu, 2005). Most of these conflicts have often been driven by ethnic contest for power, land, resources and the struggle for identity and, in recent times, political infiltrations (Osaghae, 2005). These conflicts, such as the Sudanese, Burundian and Democratic Republic of Congo's conflicts, have created deep-seated hatred and destructions with their attendant manifestations of genocide, mistrust, inequality in the distribution of power and resources among ethnic groups in these states.

Many of conflicts that occurred in Africa in the 1990s were approached with a wide range of approaches and mechanisms to regulate and resolve them through a number of resolution processes that involved the use of international statesmen, international and regional organizations, the involvement of neighboring countries, peace support operations and civil society organizations (CSOs) (Galadima, 2006; Konteh, 2006). Many of these methods of conflict resolution were thus western and conventional that did not take into account the cultural milieu of their occurrence. As a result, many of the conflicts became protracted and intractable. Even where there is a return to peace, deep-seated issues still remain to be resolved and therefore make peace in these areas fragile. This questioned the effectiveness of most of these conventional and western resolution approaches and mechanisms in Africa. The conflicts in Somalia, Sudan, Democratic Republic of Congo and Niger Delta rage on, despite efforts to resolve them. The challenges associated with the resolution approaches call for alternative resolution mechanisms that can be used to bring a final resolution to the conflicts in the continent.

Boege (2006) believes that many of the 'new wars' are permeated by traditional causes and forms of violence. Boege (2006) opines further that traditional social entities such as extended families, lineages, clans, 'tribes', religious brotherhoods and ethno-linguistic groups become parties to the conflict(s), introducing their own agendas into the overall conflict setting. Therefore, the intervention approaches to these conflicts will need traditional/indigenous methods to resolving them. Also, a hybrid of non-state traditional actors and methods (indigenous) - and their combination with modern forms of conflict transformation, be they state-based or civil-society-based could be applied in conflict resolution (Boege, 2006). 
Many of the conflicts in Ghana are traditional because many of them revolve around traditional quest for power (chieftaincy) intricately linked to land ownership. The Dagbon chieftaincy, Bunkpurugu-Yunyo, the Buipe chieftaincy and Akropong-Akwapem and Abiriw land conflicts ${ }^{1}$, for instance, are all traditional. However, approaches to resolving these conflicts right from their onset often do not adopt traditional approaches in their resolution despite the fact that they have a traditional source. As a result, many of these localized conflicts have assumed a protracted nature with occasional flaring up of violence which has negative impact on local development.

The Bawku conflict remains one of the localized conflicts that has existed for more than eight decades having it source also being traditional - the ownership of the Bawku skin ${ }^{2}$. Despite many years of efforts to resolve the conflict through CSOs and government mediation, committees of enquiry, the law courts, decrees and peace enforcement, the conflict still remains to be resolved to bring lasting peace to Bawku. The protracted nature of the conflict and frequent eruption of violence questions the current resolution methods used to resolve the conflict. Besides, indigenous methods have not been explored in attempting to resolve this conflict. Consequently, this paper examines how indigenous mechanisms in the Bawku Traditional Area $^{3}$ can be explored in resolving the ethnic conflict in the area. The remainder of the paper is organized as follows: section two discusses theoretical and conceptual issues related to the paper; the study area and history of the history of the Bawku conflict are discussed in section three; section four presents the methodology used; the empirical results and discussions are examined in section five and section six finally gives the conclusion and makes recommendations.

\section{Theoretical and conceptual issues}

Conflict occurs when two or more parties pursue incompatible interests or goals through actions that the parties try to undo or damage each other. These parties could be individuals, groups or countries. The parties' interests can differ over access to resources, the control of political or traditional power, their identity and values or ideology. The realization of these needs and interests by people can lead to conflict. When two groups or individuals such as ethnic groups pursue incompatible interests and needs which could either be political, economic, social or cultural, they can engage in conflict which can be violent.

\footnotetext{
1 These are all ethnic conflicts located in various parts of Ghana. Tsikata, D. \& Seini, W. (2004). Identities, inequalities and conflicts in Ghana. CRISE working paper. Oxford: CRISE
2 This is used to refer to the title of the paramount chief in the area. Note that the skin (of an animal) is the title of power of chiefs in Northern Ghana whilst the stool is the title of chiefs in Southern part of Ghana. Therefore there is the tendency to refer to the chieftaincy in a particular as the area skin or stool in Ghana. Hence, the name the Bawku Skin.

3 The Bawku Traditional Area is made of three administrative districts which all come under one paramount chief called the Bawku Naba (chief). These districts are the Bawku Municipal Assembly, the Bawku West Assembly and the Garu-Tempane District Assembly. Note that District Assemblies are decentralized administrative government representation at the local level in Ghana.
} 


\subsection{Conflict resolution}

Conflict resolution aims at identifying the main causes of a conflict so as to put an end to the conflict to ensure sustainable peace. The United Nations Department for Economic and Social Affairs (UNDESA) (2001) maintains that a conflict is resolved when the root causes of that particular conflict are identified and addressed. Conflict resolution seeks to design solutions through a joint-problem solving approach. When a conflict is successfully resolved, the conflict is transformed and becomes a catalyst for deep-rooted enduring positive change in individuals, relationships and structures (development) (UNDESA, 2001). Thus, successful resolution of a conflict will ensure sustainable peace which would lead to improved security and good relations among people which could lead to human well-being and general development.

Conflict resolution brings an end to a conflict where the disputing parties are satisfied and the conflict is genuinely and truly resolved. Many approaches and methods could be used in conflict resolution. These include mediation through a third party intervention, negotiation, alternative dispute resolution, collaboration, arbitration and conciliation. The appropriate method may depend to a large extent on the nature and type of conflict involved (Best, 2006). Generally, the various methods of conflict resolution are usually a process in that each requires a certain procedure and time and not just a one way approach (Best, 2006). Godongs (2006) maintains that mediation by a third party (institutions and bodies) helps to identify the root causes of conflicts in order to address them. Godongs believes that mediations are collaborative and reconciliatory to help to design solutions through a joint problem-solving approach to conflicts. With regard to the Bawku conflict, conflict resolution has been sought after with the aim of bringing the conflict to an end with almost all the methods mentioned above being in an attempt to end the conflict.

\subsection{Indigenous conflict resolution mechanisms}

Indigenous conflict resolution mechanisms comprise social, economic, cultural and religious-spiritual dimensions in accordance with the entirety of traditions, customs and world views of a society within the different spheres of societal life. The methods involve negotiations, mediations and reconciliation based on the knowledge, customs and history of the community. The process is led by leaders of the community such as traditional chiefs, kings, priests, healers, elders and other tribal leaders and takes the forms of rituals in which the whole community takes part in it. Wealth exchanges, prayers and sacrificing to the gods/ancestors are performed and there is often merry-making. In traditional African societies, conflict is often resolved using laid down traditions (Nwolise, 2005). This is because the restoration of peace, its maintenance and social harmony are prime for the welfare of the entire society. According to Pkalya, Adan and Masinde (2004), traditional social entities such as chiefs, elders of the community, extended families, lineages, clans, tribes, religious brotherhood, local institutions and ethno- linguistic groups remain important in the resolution process of conflicts. By western methods of conflict resolution, I mean the use of formal and external bodies and structures in attempting to end a conflict. 
In distinguishing indigenous conflict resolution mechanisms from western-style Werberian/Westphalia methods of conflict resolution, Castro and Ettenger (1996) state that indigenous conflict resolution mechanisms are not merely about adjudication of who is right or wrong and the punishment of culprits, but the reconciliation of the parties to end conflict. The main aim is the transformation of conflict in which both parties are satisfied and willing to "let go their pain and forgive each other." Boege (2006) describes this as "restitutive reconciliation." Thus, indigenous approaches to conflict resolution aim at restorative justice, restoration of order, harmony and the maintenance of relationships within the community through reintegrating feuding parties for true reconciliation (Boege, 2006).

Also, indigenous methods are holistic and consensus-based and often involve the participation of all parties as well as the entire community. For instance, Tonah (2007) using chieftaincy conflict that happened in the Wungu Province of the Mamprungu Kingdom ${ }^{4}$ in Ghana, describes how indigenous methods of conflict resolution helped to end the chieftaincy conflict in the Wungu Province. Stalement arose in 1996/97 following the rejection of the Nayiri's choice of Wunaba (chief of Wungu) by a section of the people of Wungu. The rejection led to the anger of the Nayiri and for a period of four years (1997-2001), the Nayir's choice was never allowed to rule in Wungu. In 2002, the people who rejected the Nayiri's choice begged for forgiveness of the Niyiri and a process of reconciliation began that involved the sacrifice of animals, merry-making and the entire community. A new chief was chosen by the Nayiri and peace and an end to the conflict.

Westphalia methods of conflict resolution such as the use of the court system and use of foreign NGOs do not lead to proper conflict resolution. The court system often leads to blame and punishment of some factions which tend to aggravate hostility among the conflicting factions and lead to the escalation of violence. Similarly, Agyeman (2008) maintains that the involvement of foreign and international NGOs in conflict resolution do not often lead to real conflict resolution at the local level. This is because most of these foreign NGOs do not know the local roots and dynamics in these conflicts and are not therefore in position to prescribe local solutions to the real termination of conflicts (Agyeman, 2008). He therefore calls for the use of local entities such as the houses of chiefs and community based organizations in resolving local conflicts. The Bawku conflict which is the focus of this paper has seen the numerous involvements of local, international and foreign NGOs in its resolution but the conflict is yet to see a termination of violence and true resolution.

In addition, Kirby (2006) believes that western-conventional methods of conflict resolution in Northern Ghana have failed in resolving conflicts. Many of the parties in these conflicts have resorted to the court system of resolution and use of foreign NGOs which has not helped to address the root causes underlying them. Kirby (2006) states that conflicts need to be understood in the milieu of cultural context rather than adopting western methods which are

\footnotetext{
${ }^{4}$ The Mamprungu Kingdom is located in the Northern Region of Ghana. The Nayiri is the paramount chief of all Mamprusis in Ghana. The Mamprungu Traditional Area has five paramouncies of Wungu, Janga, Kpasenkpe, Yunyoo and Kurugu with the headquarters in Nalerigu.
} 
not culturally sensitive and contextual to many of the conflicts around us. The key to good conflict resolution requires entering deeply into cultural issues at all levels and also considering the ritual dimensions to the issues at conflict (Kirby, 2006). Kirby observes further that conflict resolution in Northern Ghana and elsewhere in Africa is not a two dimensional "negotiation" between the combatants, but involves a three dimensional "reconciliation" between the combatants and more importantly for all others suffering the negative effects of the conflict though not directly involved, and reconciliation with the "Earth".

Kirby (2006) posits that addressing ethnic conflicts in Northern Ghana and elsewhere demands using local beliefs, values and attitudes as well as local contexts, procedures, actors and practices. These beliefs, values and practices must engage an understanding of local cultures of reconciliation based on African Traditional Region (ATR). The rituals with regard to the earth cult in most tribes in Northern Ghana play important roles in conflict resolution and reconciliation and these rituals of the earth cult involve sacrifices, prayers and appeasing the spirits for proper reconciliation to take place (Kirby, 2006). This is unlike western-style resolution of conflicts which impose "foreign" methods and practices into conflicts making it difficult for true reconciliation to take place (Kirby, 2006). In all, indigenous methods of conflict resolution are all encompassing methods that combine a number of conflict resolution mechanisms including mediation, negotiation and reconciliation.

\section{Study area}

The study was conducted in the Bawku Traditional Area which covers three districts within the Upper East Region of Ghana. These districts are the Bawku Municipality, Bawku West District and the Garu-Tempane District. The Bawku Traditional Area covers all the areas under the Bawku Skin (paramountcy) and has over 150 communities. According to the 2010 Population and Housing Census Report, the Bawku Traditional Area has a total population of 441,828 (Bawku Municipality 217,791 Bawku West 94,034 and Garu-Tempane 130,003) (Ghana Statistical Service, 2012).

The Traditional Area is located at the north-eastern part of the Upper East Region and bordered to the north by Ghana's boundary with Burkina Faso, the south by the East Mamprusi District, to the west by the Talensi-Nabdam District and to the east by Ghana's boundary with Togo (Marks Publications and Media Services, 2010). It is the largest traditional area in the region and covers an area of about 3,076sq km which constitutes $34.8 \%$ of the region's total land area of 8, $842 \mathrm{sq} \mathrm{km} \mathrm{(Ghana} \mathrm{Statistical} \mathrm{Service,} \mathrm{2012).} \mathrm{According} \mathrm{to}$ the Bawku Municipal Assembly (2006), the area lies in the savannah woodlands characterized by drought-resistant trees and grass which are susceptible to bushfires during the dry season. As with the whole of the Upper East Region, the Bawku Traditional Area is part of the interior continental climatic zone of the country characterized by pronounced dry season which is long and a rainfall pattern which is erratically spatial in duration (Marks Publications and Media Services, 2010).

Politically, there are two levels of authority in the Traditional Area - the local government 
authority and traditional authority. The local government authority represented by the district assemblies provides administration at the local level and are headed by district chief executives. In accordance with the Local Government Act, PNDC Law 207, 1988, the District Assembly is the highest political and administrative authority. The assembly works with decentralized departments for the administration and development of the district. The traditional authority embodies the chieftaincy institution which has the Bawku paramountcy as the head. The traditional authority has been the source of conflict in the area between the Kusasis and Mamprusis.

There are many ethnic groups in the Traditional Area. These are Kusasi, Mamprusi, Hausa, Mossi, Bimoba, Busanga, Frafra and Dagomba with the Kusasi forming the majority (Ghana Statistical Service, 2012; Marks Publications and Media Services, 2010). Rattary (1932) indicates that most of the ethnic groups are migrants to the present area and actually settled in the area for many years. Ethnic heterogeneity has had implications for ethnic relations and harmony in the traditional area since this has led to conflict in the area. This is seen in the relations between the Kusasis and Mamprusis which has spread to affect the relations with other ethnic groups.

\subsection{History of the Bawku conflict}

The Bawku conflict is a deep-seated and longstanding ethno-political conflict between the Kusasis and Mamprusis ${ }^{5}$ in the Bawku Traditional Area of Ghana. The conflict is identity-based, and revolves around the claim for traditional political power (chieftaincy) between the Kusasis and Mamprusis. The contest between the Kusasis and Mamprusis over the Bawku chieftaincy has its roots in colonial times. Bawku remains the most important town in the three administrative districts that make up the Traditional Area (Bawku Municipality, Bawku West District and the Garu-Tempane District) because of its commercial location and the paramountcy. The area is divided into Agolle, east of the White Volta and Toende, west of the White Volta. According to the Kusasis, they were the first to settle in East Agolle, now the Bawku area which comprises all areas under the Bawku skin (Rattray, 1932). The Kusasis lived in the area for many years and became the tindaanas ${ }^{6}$ (earth priests) of the area (Awedoba, 2009). The Kusasis were traditionally farmers and deeply rooted in their traditions. They worshipped the cult of the earth spirit and other gods (Rattray, 1932). The Kusasis population grew in the 1900s and they occupied many areas in Agolle and Toende ranging from Bawku to Zawse, Pusiga, Yaragungu, Tampelungu, Sapelliga, Nyokko, Binduri, Garu, Zebilla, Tempane ${ }^{7}$ and other places (Hilton, 1962). Bawku grew steadily as the centre and largest town and became the capital of the local council when the Northern Protectorate was formed in $1907^{8}$ (Hilton, 1962).

\footnotetext{
5 These are two ethnic groups who are fighting for the chieftaincy in the Bawku Traditional.

${ }^{6}$ In Northern Ghana, the earth priest is the spiritual owner of the land and worships the spirit of the earth (earth god). In pre-colonial times, they were regarded as owners and keepers of the land. Note that the term tindaana is same for most of the Gur-speaking languages of Ghana.

7 These are all areas within the Bawku Traditional Area.

8 This was how the British colonizers referred to the Northern part of Ghana.
} 
The Mamprusis also claim that Bawku, since pre-colonial days, has been under their rule and the Kusasis migrated to their present locations from Bugri, Yauga and Ayua, all in Burkina Faso (Awedoba, 2009). Mamprusi rule in Bawku was necessitated by the slave raids and invasions of the Mamprusis important trade routes which the Nayiri ${ }^{9}$ sought to protect. The Kusasis who did not initially resist the Mamprusi rule, started agitating for their own chiefs and the need to rule themselves in the 1930s.

The ethnic conflict between the Kusasis and Mamprusis in the Bawku Traditional Area dates back to 1931 with the Kusasis' claim over the Bawku skin Bombande (2007). The institution of chieftaincy which is the main source of conflict was introduced by the Mamprusis who mounted security posts to safeguard their important trade routes between Gambaga and Tenkudugu around the sixteenth century (Kusimi et al., 2006). Also, the Opoku-Afari Committee (1957) intimated that the Mamprusis presence in Bawku was necessitated by the constant raid of traders from Gambaga by Kusasi bandits. Among the first Mamprusi settlers in Bawku are Prince Ali, son of Naa Atabia, (the Nayiri of the Mamprusis) who was mandated by the Nayiri to establish a 'police post' at Bawku to safeguard their routes (Bombande 2007). From this time, around the sixteenth century, the Bawku skin came directly under the Nayiri who had the authority to install the Bawku Naba ${ }^{10}$ and enskin ${ }^{11}$ other chiefs at Binduri, Teshie, Tanga, Sinibaga, Warikambo and other places. The Kusasis did not initially resist the various Mamprusi successions to the Bawku skin (Lund, 2003).

According to Bombande (2007), up till the 1930s, the Mamprusi jurisdiction did not extend to all the Kusasi settlements and the whole traditional area. Their authority was, however, consolidated to include all Kusasi areas following consultations with the colonial district commissioner in 1931 which made the Bawku Naba (paramount chief of the Traditional Area) the chief of the Bawku Traditional Area including Bawku, Zebila, Garu, Tempane, Binduri, Warikambo and Teshie ${ }^{12}$. From 1731, only Mamprusis had ascended to the Bawku skin. However, in 1957, competing claims between the Mamprusis and Kusasis over the Bawku skin resulted in the installation of two different chiefs for the same skin: Abugrago Azoka for the Kusasis and Mahama Yiremia for the Mamprusis (Opoku-Afari Committee, 1957). This led to some disturbances and intensified the claim over the Bawku skin.

The resulting disturbances compelled the Governor General, Lord Listowel ${ }^{13}$, to set up the Opoku-Afari Committee of 1957 to enquire into the causes of the disturbances. The

\footnotetext{
${ }^{9}$ The Nayiri is the paramount chief of all Mamprusis in Ghana. He is headquartered in Nalerigu in the Northern Region of Ghana

10 The Bawku Naba is the paramount chief of the Bawku Traditional Area.

11 This is the process of installing a chief in Northern Ghana.

12 These are all areas within the Bawku Traditional Area.

${ }^{13}$ He was the last representative of the Queen of Britain in Ghana.
} 
committee reported among other things that "the Nayiri's practice of selecting and installing a Mamprusi prince as chief of the Kusasi area is undemocratic and dictatorial" and consequently upheld the installation of Naba Abugrago Azoka as legitimate and in accordance with the Kusasi traditions (Opoku-Afari Committee, 1957, p. 13). Following the committee's report, the Governor General recognized Abugrago Azoka as the Bawku Naba. Aggrieved by the decision, the Mamprusis filed a writ in the divisional court requesting the court to quash the proceedings and report of the committee of enquiry, as well as the decision of the Governor General. Though their request was granted, the Court of Appeal ${ }^{14}$ overturned the decision of the divisional court's ruling (Bombande, 2007).

Soon after independence in 1957, the conflict took different twists as there were various alignments of the two ethnic groups to political parties in order to win favour. The Kusasis supposedly enjoyed the support of the Convention Peoples Party (CPP) ${ }^{15}$ Government whilst the Mamprusis enjoyed the support of the United Party (UP), the opposition party at the time. These alignments according to the two factions were for electioneering support for these two political parties (CPP and UP) (Adam, 2008). The CPP Government accepted the verdict of the Appeal Court's ruling which upheld Abugrago Azoka as the Bawku Naba. This was seen by the Mamprusis as support for the Kusasis by the Nkrumah and his CPP government because they believed the Kusasis had supported him during the 1957 election. After the court decisions, the conflict seems to have died down and resolved.

This seeming peace soon eroded in 1966 following the overthrow of the CPP Government by the military regime of the National Liberation Council (NLC). The chieftaincy Amendment Decree, NLCD 112 (1966), was passed by the military regime of the National Liberation Council (NLC). The Decree in effect placed all newly created paramountcies since 1957 under their former paramount chiefs (Bombande, 2007). Though the decree clearly sought to reverse the decision of Nkrumah and the CPP government, which the NLC and its functionaries felt were aimed at rendering certain chiefs powerless, its application in the case of the Bawku paramountcy renewed the tension between the Kusasis and Mamprusis. By the Decree, the Mamprusis became the paramount chief of Bawku once again, and the Nayiri regained the right to select and install the Bawku Naba and Adam Azangbeo, a Mamprusi, was enskinned $^{16}$ Bawku Naba (Bombande, 2007).

The Progress Party (PP) which won the 1969 elections also pursued the line of political interference as most of the Mamprusis were key elements of the government. The PP Government apparently supported a number of structural changes in the Bawku chieftaincy case (Akwetey, 1996). The name of the district for example was subsequently changed from Kusasi District to Bawku District and the traditional council changed from Kusasi to Bawku Traditional Council (Akwetey, 1996) which were supported by Mamprusis and opposed by

\footnotetext{
14 This was the highest court of Ghana at the time.

15 It was the party of Ghana's first president Dr. Kwame Nkrumah.

16 The past tense form of eskin (to install/crown a chief).
} 
Kusasis.

From 1970 to 1980, Adam Azangbeo, a Mamprusi, ruled Bawku despite opposition from the Kusasis. However, following the military takeover by the Provisional National Defence Council (PNDC) in 1981, the Kusasis again found solace with the new government and petitioned it. In 1983, the Provisional National Defence Council (PNDC) passed the PNDC Law 75 (the Restoration of Status of Chiefs Law), which reversed the NLC Decree 112 and restored all the affected paramountcies to their former status as independent paramountcies. Consequently, Adam Azangbeo was deskinned ${ }^{17}$ with all the 18 sub-chiefs and Ninchema Abugrago Azoka II, son of the first Kusasi Bawku Naba (Abugrago Azoka), was enskinned making Bawku a Kusasi paramountcy once again.

Since that time (1983), this has degenerated into violent confrontations between the two ethnic groups and this keeps unending due to failure to resolve the conflict. This failure to resolve the conflict seems to have made it protracted. The two ethnic groups have had violent confrontations several times in 1983, 1984, 1985, 2000, 2001, 2007, 2008, 2009 and 2010. The CPP and UP (PP) interferences in the conflict in recent times have metamorphosed into the NDC and NPP ${ }^{18}$ which enjoy the support of the Kusasis and Mamprusis respectively. The 2000 clash, for instance, was necessitated by supposed clashes between supporters of the NDC and the NPP (Brukum, 2001).

Following the intensity of violence and the inability of the state to resolve the conflict, a number of CSOs/NGOs had to come in to help resolve the conflict. These include international and community based NGOs. WANEP and the Catholic Relief Services (CRS) have been particularly instrumental in bringing the parties and all other ethnic groups in the area to a round table discussion at Damango ${ }^{19}$ in 2001 and Kumasi ${ }^{20}$ in 2010 for peace talks and mediation. Many CSOs/NGOs have still been involved in making attempts to resolve the conflict.

\section{Methodology}

The study adopted a qualitative approach in both its analysis and data collection. A descriptive case study approach was used for a detailed description of the ethnic conflict and the indigenous mechanisms that exist in the area. A total of 42 respondents were interviewed for the study. The respondents were traditional actors comprising chiefs and community elders (ethnic/community leaders and tindaanas) from the two feuding ethnic groups (Kusasis and Mamprusis). They were selected using the purposive sampling method because they are the two claiming ownership of the Bawku Skin and therefore gave detailed description of the indigenous methods. Fourteen communities in the area were also purposively drawn, taking

\footnotetext{
17 This means to dethrone a chief in Northern Ghana.

${ }^{18}$ NDC is the National Democratic Congress (the ruling party in Ghana since 2009) and NPP is the New Patriotic Party (the main opposition party. This party has roots in the UP (PP)).

${ }^{19}$ Damango is the capital of the West Gonjo District Assembly of the Northern Region of Ghana.

${ }^{20}$ Kumasi is the capital of the Ashanti Region of Ghana and home to the Great Ashanti king.
} 
into consideration the fact that they had been the scenes of the conflict. These communities were mainly in the Bawku Municipality (BMA) because the conflict is mainly centered in the BMA. Zebilla and Garu in the Bawku West District (BWDA) and Garu-Tempani District (GTDA) respectively were also purposively chosen because they did have occasional outbreak of violence. The data were transcribed and a content analysis of the transcribed data was done.

\section{Empirical results and discussions}

This section of the paper discusses the views of respondents on indigenous conflict resolution methods in the Bawku Traditional Area highlighting the conflict resolution methods of both the Kusasis and Mamprusis.

\subsection{Methods used in attempting to resolve the Bawku conflict}

Many approaches have been used over the years in attempting to resolve the Bawku conflict. These include mediation, reconciliation, peace keeping, and arbitration. These efforts have been through committees of enquiry, the law courts, mediation, decrees and peace enforcement mainly by government. Government has used over the years deployed security agencies made up of the police and the Rapid Deployment Force (the army) to the area to maintain peace during occurrence of violence. Besides, governments use imposition of curfews whenever violence occurs to mitigate the effects of the conflicts. Moreover, the court system has been used as a means of trying to end the conflict since 1957. Various rulings have been made by the courts with regard to the conflict. These include the divisional court ruling of 1957, the Court of Appeal ruling of 1958, and the Supreme Court ruling of 2003 (Bukari, 2011). This confirms Awedoba's (2009) assertion that the law courts have dealt with the issue since the 1950s. The use of arbitration remains one of the main methods of attempting to resolve the conflict over the years. These arbitrations have been through the national and regional houses of chiefs ${ }^{21}$. For example, the National Chieftaincy Tribunal of the National House of Chiefs arbitrated in the Bawku case and gave its ruling on $20^{\text {th }}$ May, 1982 in favour of the Mamprusis (Report of the Ruling of the National Chieftaincy Tribunal of the National House of Chiefs, 1983). Up to date, the conflict is still at the Tribunal of the National House of Chiefs awaiting their verdict.

NGOs have also been using mediation, peace dialogues and peace education and sensitizations. A number of CSOs /NGOs since 2001 have made efforts at mediating to end the conflict through peace building processes and conflict resolution mechanisms. These efforts include the Bawku Peace Accord reached between the stakeholders in the conflict at the Damongo Peace Agreement, which was spearheaded by a consortium of CSOs mediating in the conflict, including Action Aid Ghana, the West African Network for Peacebuilding (WANEP), Advocacy Peace Group - IBIS (Ghana), the Catholic Relief Services (CRS), the Christian Council of Ghana and the Bawku East Women's Development Association (BEWDA). NGOs together with the National Peace Council (NPC) ${ }^{22}$ have also

\footnotetext{
${ }^{21}$ At the district, regional and national levels in Ghana, the traditional authorities have councils that look into chieftaincy issues including the arbitration, adjudication and settlements of chieftaincy conflicts.

${ }^{22}$ The National Peace Council (NPC) is a body established by the Government of Ghana to promote peace-building and
} 
mediated and drawn up a roadmap to peace.

A critical look at all these measures at resolving the conflict indicates that the conflict still remains unresolved and many of them are formal western methods (mainly arbitrations). I believed that most of these methods rather attempt at managing the conflict to reduce the spate of violence and killings than conflict resolution that will see the end of the conflict and get to true resolution of the conflict.

\subsection{The Bawku Inter-Ethnic Peace Committee (BIEPC)}

The study found that there was the formation of an inter-ethnic peace committee to help in resolving the long protracted conflict. The committee known as the Bawku Inter-Ethnic Peace Committee (BIEPC) is made up of 20 members comprising all ethnic groups within the area. These groups are Kusasis, Mamprusis, Mossis, Busangas, Hausas, and Dagombas. The BIEPC is co-chaired by a Mamprusi and a Kusasi. The BIEPC was formed in 2009 by the efforts of government through the National Peace Council (NPC) and other CSOs working for peace in Bawku and reinforced following the Kumasi Peace Talks in 2010 facilitated by the West African Network for Peacebuiding (WANEP) which was attended by all stakeholders comprising chiefs, tribal leaders, political leaders, youth and women groups and NGOs working for peace in the area. The BIEPC was formed mainly to allow the people of Bawku to negotiate in order to find a 'self-solution' to their own conflict. According to the two co-chairmen of the BIEPC, the committee sought to use mainly traditional approaches in resolving the conflict.

Committee members interviewed indicated that the committee was in the process of meeting the various factions to lay down their arms to stem down the violence in the area and also release seized lands back to their owners particularly Mamprusis. A process of purifying the land was started through the "rites of the cult of the earth" and prayers by all religious groups after which the committee was to organize a cleansing ceremony in which all feuding factions wiould pledge their support to the end of the violence. This is what the BIEPC termed 'pacification, prayers and reconciliation.' The use of the BIEPC in resolving the conflict is in consonance with Agyeman's (2008) proposal that ethnic conflicts in Ghana can be effectively resolved through empowering and strengthening decentralized structures of governance at the local level to deal with these conflicts and establishing joint consultative committees comprising representatives from the warring factions in the resolution of ethnic conflict.

\subsection{Tradition and conflict resolution in the Bawku Traditional Area}

Every society has its way of resolving conflict which is made up of the traditions of the people (Nwolise, 2005). All the traditional actors in Bawku said that traditional mechanisms exist in the area in resolving conflicts. They mentioned the family system, the clan and the community levels at which conflicts are resolved. The Kusasis mentioned the use of the rites

provide mechanisms through which Ghanaians can seek peaceful, non-violent resolution of conflicts. It was established in August 2006 after many concerns about the upsurge of ethnic and communal violence in Ghana. 
of the earth cult in which there is blood cleansing rites, purification rites, blood collecting and sacrifice of animals as a major way of conflict resolution. The use of the rites of the earth cult is a major method of conflict resolution in Northern Ghana (Kirby, 2006). Respondents also stated the use of chiefs, elders and opinion leaders in resolving conflicts in the area. As to whether these methods have been applied in resolving the current conflict, respondents agreed that some of the methods have been used to help resolve the conflict, but have failed to bring the conflict to an end. Many of the respondents, however, said that the use of the rites of the earth cult have yet to be used in resolving the conflict.

\subsection{Kusasi methods of traditional conflict resolution}

According to Kusasi tradition, conflict is an infringement on the gods and the spirits of the earth. They therefore assert that when conflicts occur and human blood is shed, the gods and spirits of the earth need to be pacified to avoid calamity on human beings. Kusasis, according to traditional actors, are religious and therefore believe that the return of peace after violent conflict involves the rites of the earth cult. As to how this traditional method (the rites of the earth cult) can be applied in resolving the conflict, respondents mentioned that the use of the rites of the earth cult among the Kusasis involves three main processes: blood-collecting and blood cleansing, burial of objects and merry making.

\subsubsection{Blood-collecting and blood cleansing.}

The first step of the performance of the rites of the earth cult is blood-collecting and blood cleansing. This involves sacrificing animals to pacify the land in areas where human lives were lost during the conflict. Here, a goat and a cock are killed and used with "pito" (a local brewed beer) to pacify the land. According to respondents, the sacrificed animal is often roasted and eaten by the conflicting parties together. The eating of the together sacrificed animal by the conflicting parties signifies their resolve to work together towards peace. Twenty three (23) areas, according to the Bawku Naba, have been identified in the traditional area (the Bawku Traditional Area) for the rites of purification. All these areas will be cleansed through traditional rites of sacrifice to plicate the land for the desecration which involved the shedding of human lives. One Kusasis traditional respondent observed that:

Tindaanas (chief priests) of the respective areas normally perform these rites with the invocation of incantations calling on the spirit of the earth god to forgive us humans for we have erred against her (the earth-god). This rite (Blood-collecting and blood cleansing) is important since it is the first step to making peace in any conflict situation. Failure to accomplish this rite renders the subsequent rites null and void

\subsubsection{Burial of objects}

The second involves the burying of objects to signify the end to hostilities. This is done immediately after animal sacrifices are performed. An okro stalk is buried into the earth by both factions in the conflict signifying end to fighting and bloodshed. This is very symbolic and the okro stalk becomes sacred to the earth spirit as a promise by the factions to stop 
shedding blood and embrace peace. The punishment for anyone who breaches the peace is death. One of the Kusasis traditional actors narrates that:

Burying objects as a rite of the earth-cult among us Kusasis is very serious since it is an agreement between you and the earth-god that you will not shed any more human blood on the earth. This is particularly serious when the okro stalk is used. When you break this and fight, death becomes your punishment and this affects your family lineage as well.

This rite would have to involve the presence of both factions in the conflict who together go into agreement with the spirits to end all forms of violence and make peace. The successful completion of this rite signifies the return of peace and final resolution of conflict.

\subsubsection{Merry making}

Finally, merry making is organized at a grand ceremony usually in the traditional capital and seat of the paramountcy (in this case Bawku) where all the parties involved in the conflict come together to celebrate and declare their support for peace in the area. This occasion according to them will involve all the parties, community members and government functionaries. During this occasion, final animal sacrifices are made purposely to prepare for the merry-making. It involves singing, drumming and dancing by factions

These rituals and processes are not new and are consistent with the study of Kirby (2006) of northern tribes in Ghana. His study found that the rituals of the earth cult through sacrifices, prayers and appeasing the spirits in most tribes in Northern Ghana play important roles in conflict resolution because it allows for proper reconciliation to take place

\subsection{Mamprusi methods of traditional conflict resolution}

Mamprusi traditions equally see peace as necessary for the advancement of society. Therefore, violence is abominable to the gods and God. A Mamprusi elder opined that Mamprusis are equally very traditional and follow their traditions very well. He, however, said that majority of Mamprusis today are Muslims and do not believe in animal sacrifices to the gods. On the methods adopted by the BIEPC at the Kumasi talks, five of the Mamprusi respondents expressed reservations about the use of the methods in resolving the conflict because to them, these methods are not all-encompassing and acceptable to them since they do not believe in them. They claim that the approaches to be used by the BIEPC are biased since they are mainly Kusasi and the methods conflict with their beliefs (Islam). One of the Mamprusi respondents noted that:

Even if we want to accept this method, the questions I ask is: do these methods conform to our (Mamprusi) own traditions? And is our father (the Nayiri at Nalerigu) part of this whole decision before it was arrived at?

Mamprusi traditions require peacemaking to first of all come from following laid-down traditions. The Mamprusis claim that the first step to making peace and reconciliation is to go back to the Nayiri (the overlord of all Mamprusis in Ghana) who is the overseer and owner of Bawku. A Mamprusi respondent maintains that: "traditionally, it is the Nayiri who enskins a chief for Bawku and therefore, we both have to go back to him to decide who can become 
Bawku Naba." Thus, the first step is reconciling with the Nayiri by appeasing him and apologizing for his forgiveness through the presentation of an animal (cow) to him. When this is done and the Nayiri accepts the gift (cow), he then takes the 'chieftaincy back' (the Bawku Skin) since he is the sole person to enskin a Bawku Naba. According to one of the Mamprusi elders: "when this is done, the Bawku conflict can be resolved since the long-held tradition would have been obeyed."

Besides, Mamprusis believe that the houses of chiefs (the National and Regional Houses of Chiefs) should also be allowed, independent of the influence of government and politicians, to use laid down tradition and history to pronounce the real owners of the Bawku skin. This is because National and Regional Houses of Chiefs have the backing of Ghana's Constitution to settle chieftaincy disputes. This to them will help resolve the conflict.

\subsection{Using traditional methods of conflict resolution in the Bawku conflict.}

A critical study of the use of traditional methods of resolution in the Bawku conflict reveals the following:

First of all, the 2010 Kumasi Peace Talks did not actually arrive at acceptable and all-encompassing traditional resolution methods at resolving the conflict, although the communique issued at the end of the talk was signed by both factions and all stakeholders. The current methods to be used by the BIEPC are not acceptable particularly to the Mamprusis. Although, one of the co-chairman of the BIEPC told me that it was due to lack of funds that the committee's program of using traditional methods to resolve the Bawku conflict has stalled, it is obvious that the methods do not adopt an integration of both factions (Kusasis and Mamprusis) traditions to resolve the conflict. The question is how the traditional resolution methods of both ethnic groups can be integrated since the traditional resolution methods of both factions are completely at variance?

The BIEPC, as of the time the study was being conducted, saw a withdrawal of the Mamprusis from the committee (BIEPC) accusing the BIEPC of bias in favour of the Kusasis and lack of commitment to the Peace process in Bawku. My interview with Mamprusi elders and opinion leaders reveal lack of trust and faith in the work of the BIEPC. Up to-date, the BIEPC has not been able to achieve what it aims to do by using mainly traditional approaches to resolve the conflict.

Moreover, the entrenched positions taken by both factions make the use of traditional methods very difficult. While the Mamprusis believe that the best traditional approach to the conflict is the use of laid-down and long-held tradition which is going back to the Nayiri who they see as the only one who can enskin a Bawku Naba, the Kusasi believe that the right to enskin a Bawku Naba rests with Kusasi traditions and that the Kusasis are the owners of Bawku and have the right to enskin their own chiefs according to Kusasi traditions.

The conspicuous exclusion of the Nayiri in the resolution process of the Bawku conflict is a 
serious impediment to achieving peace and resolving the conflict. The Mamprusis' hold to the Nayiri as the overseer and owner of Bawku reveals their recognition, trust and confidence in the Nayiri as the only solution to the conflict. The Kumasi Peace Talks should have made the Nayiri an integral part of the resolution process and the BIEPC. The Nayiri's exclusion from resolution efforts actually makes it difficult to achieve peace since he is an interested party in the Bawku conflict.

Before any resolution effort can be made to end the conflict in Bawku, there is the need to cease all violence and fighting to allow for negotiation or mediation. The Kumasi Talks did very well by bringing the factions to a round-table discussion on how to end the conflict. However, since the talks, there has been violence and up to date, occasional violence breaks out leading to the death of people. The seeming peace is even very fragile as tensions are still high and violence in this election year in Ghana (2012) in Bawku is possible.

The application of traditional methods of resolving the Bawku conflict will need an acceptance of traditional resolution of both ethnic groups. It is important to adopt traditional approaches which are acceptable and cultural-sensitive to both ethnic groups. The rites of the earth-cult have some similarities in both ethnic groups - especially the aspect of appeasing the gods/God where efforts are made to present an animal to God/gods to appease them to enable peace to prevail. Thus, the prayers, pacification and reconciliation rites. Both sides can agree to appease the gods/God by performing these rites after which they publically come together to announce the end of violence and their resolve to enter into negotiations to deal with the substantive issue in contention (the Bawku skin). In applying rites of the earth-cult, the view of the Mamprusis for the inclusion of the Nayiri in traditional methods needs a critical consideration. This is because the Nayiri remains very necessary and important to the Mamprusis since his call on the Mamprusis to stop their contestation for the Bawku chieftaincy could bring this long conflict to an end. Thus, the BIEPC must integrate the traditional approaches of the two factions to help resolve the conflict. It is equally crucial to identify challenges and weaknesses of the traditional approaches/methods to be used by the BIEPC and deal with them to ensure the participation of all ethnic groups and parties in the peace process

The issue of the involvement of the Nayiri in negotiation efforts is very contentious and needs to be considered carefully by the BIEPC seriously. The Mamprusis insistence on the Nayiri as the one who is the traditional solution to the Bawku conflict is vehemently rejected by the Kusasis. However, it is important for the BIEPC and other stakeholders to do everything to get the Kusasis to allow the Nayiri to be part of the negotiations to end the conflict. I am not by this asking the Kusasis to accept decisions that the Nayiri impose on them but for both sides to reach a comprise favourable to both of them.

\section{Conclusion}

The mere application of traditional methods may not necessarily end the Bawku conflict if feuding factions do not agree first of all as to what traditional methods to use; secondly, how 
they should use these traditional methods; thirdly, if the factions do not agree to end violence completely; and lastly, if entrenched positions are not softened.

Also, there is the need for government to fund the activities of peace building activities. The current Bawku Inter-Ethnic Peace Committee (BIEPC) must be resourced and funded to help build peace and resolve the conflict. This is because one great challenge of the BIEPC is lack of funds to carry out its peace activities. Also, the seeming lack of transparency and fairness, perceived by the Mamprusis in particular, in dealing with issues in the area such as the handling of security issues by the security agencies and the celebration of traditional festivals need to be seriously dealt with through dialogue. The committee must also work independent of state or government interference. CSOs/NGOs must rather facilitate the activities of the committee towards self-negotiation. The involvement and inclusion of the Nayiri in all future negotiations and mediation efforts are paramount in the peace building and conflict resolution process. This is because of the power and recognition he has among the Mamprusis and can help to find a solution to the conflict.

The use of the court system (arbitration and adjudication) tends to polarize the area further and does not bring a resolution of the conflict. This is because the use of the court system since the 1950s has not helped to end the conflict, but rather polarize the area. Parties to the conflict must recognize the need to engage in dialogue rather than resorting to the court system for redress.

There is the need for a proper stakeholder analysis of actual parties in the conflict to engage them in the negotiation and mediation process. Very often, key stakeholders are not involved in the conflict resolution process and all need to be identified and brought on board in the resolution process. These stakeholders include youth and women groups and people from the other parts of the traditional area like Zebilla and Garu, who often are not included in mediation and negotiation processes.

In a nutshell, it is also possible for the two ethnic groups (The Kusasis and Mamprusis) in this conflict to consider power sharing as an alternative. This power-sharing can be fashioned out such that either each group has its own chiefs which rule its people or the power is rotational between the two ethnic groups. This can be done through proper laid-down procedures and clear-cut rules about the power-sharing.

\section{References}

Agyeman, D. K. 2008. Managing diversity and ethnic conflicts. In: Ghana Governance in the Fourth Republic. Agyeman-Duah, B. (Ed.), Digibooks Ltd, Tema. Pp: 77-96.

Awedoba, A. K. (2009). An ethnographic study of Northern Ghanaian conflicts: Towards a sustainable peace. Saharan Publishers, Legon-Accra.

Bawku Municipal Assembly. (2009). Bawku Municipal Medium Development Plan.2006-2009. Bawku Municipal Assembly 
Berinyuu, A. A. (2011). The role of stakeholders in conflict management. A paper presented at the National Conference on Conflict Management and Peace-building for Poverty Reduction in Ghana: Engaging Academia and Practitioners. Organized by CCEIR-UDS and Ghana National Commission for UNESCO. $14^{\text {th }}-16^{\text {th }}$ November, 2011.

Boege, V. (2006). Traditional approaches to conflict transformation: Potential and limits. Breghof Research Centre for Constructive Conflict Management. http://www.berghof-handbook.nd(Accessed on March 10, 2010).

Bombande, E. (2007). Conflicts, civil society organizations and community peace building practices in Northern Ghana. In Ethnicity, conflicts and consensus in Ghana. Tonah, S. (Ed.), Woeli Publishing Services, Accra. Pp: 196-228.

Bukari, N.K. (2011). Conflict and development in the Bawku Traditional Area. Unpublished Thesis in partial fulfillment of the requirements for the degree of Master of Philosophy (Peace and Development Studies), Institute for Development Studies, University of Cape Coast, Ghana.

Castro, A. P. and Ettenger, K. (1996). Indigenous knowledge and conflict management: exploring local perspectives and mechanisms for dealing with community forestry disputes. Paper Prepared for the United Nations Food and Agriculture Organization, Community Forestry Unit, for the Global Electronic Conference on "Addressing Natural Resource Conflicts Through Community Forestry. January-April 1996.

Coleman, P. T. (2000). Intractable conflicts. In: The handbook of conflict resolution: Theory and practice. Deutch, M. \& Coleman, P.T. (Eds.), JosseBass, San Francisco. Pp: $428-450$.

Coser, L. (1956). The functions of social conflict. the Free Press, New York.

Faleti, S.A. (2006). Theories of social conflicts. In: Introduction to peace and conflict studies in West Africa: A Reader. Best, G.S. (Ed.). Spectrum Books Ltd Ibadan. Pp: 35-60.

Francis, D. J. (2006). Peace and conflict studies: An African overview of basic concepts. In: Introduction to peace and conflict studies in West Africa: A Reader. Best, G.S. (Ed.). Spectrum Books Ltd Ibadan. Pp: 15-35.

Galadima, H. (2006). Peace support operations in Africa. In: Introduction to peace and conflict studies in West Africa: A Reader. Best, G.S. (Ed.). Spectrum Books Ltd Ibadan.

Ghana Statistical Service. (2012). 2010 population and housing census: Summary report of final results. Accra: Statistical Service

Idowu, W. (2005). A philosophical analysis of conflicts in Africa. In: Perspectives on peace and conflict studies in Africa, Olawale, I. A. (Ed.). John Archers Publishers Ltd, Ibadan. Pp: 10-27.

Kaldor, M. (2007). New \& Old Wars: Organized Violence in a Globalized Era. 2nd Edition. Stanford University Press, Stanford.

Kendie, S.B. \& Akudugu, M.A. (2010). Application of game theory in the management of Qnatural resources conflicts: the case of the Bongo District. A Paper prepared for the 2010 Harmattan School Series. University for Development Studies (UDS), Centre for Continuing Education and Interdisciplinary Research (CCEIR). 


\section{Macrothink}

Kirby, J.P. (2006). The earth cult and the ecology of peace building in Northern Ghana. In: African knowledge and sciences: Understanding and Supporting the ways of Knowing in Sub-Saharan Africa, D. Miller, D. Kendie, S. B., Apusigah, A. A. and Harverkot, B. (Eds.) Barneveld: COMPAS. Pp: 129-148.

Konteh, R. (2006). Responding to conflict: The role of civil society in West Africa. In: Introduction to peace and conflict studies in West Africa: A Reader. Best, G.S. (Ed.). Spectrum Books Ltd Ibadan. Pp: 272-294.

Kusimu, J., et. al.(2006). Conflicts in Northern Ghana. : A mirror of answers to sub-regional stability and security questions. Journal of Asteriskos. 1(2), 209-228.

Lund, C. (2003). Bawku is still volatile: Ethno-political conflicts and state recognition in Northern Ghana. Journal of Modern African Studies, 414, 587-610.

Mahama, I. (2003). Ethnic conflicts in Northern Ghana. Tamale: Cyber Systems.

Marks Publications and Media Services. (2010). Districts in Ghana. GhanaDistricts.com. http://www.Ghanadistricts.com/home/?=42. 2010, June 12.

Nwolise, O. B. C (2005). Traditional modes of bargaining and conflict resolution in Africa. In: Perspectives on peace and conflict studies in Africa, Olawale, I. A. (Ed.). John Archers Publishers Ltd, Ibadan. Pp: 152-168.

Osaghae, E. F. (2005). Violence in Africa: State, ethnic and regional dimensions. In: Perspectives on peace and conflict studies in Africa, Olawale, I. A. (Ed.). John Archers Publishers Ltd, Ibadan. Pp: 100-121.

Opuku-Afari Committee. (1957). Bawku affairs: Report of the committee appointed by His Excellency the Acting Governor-General to inquire into the claim of Abugurago Azoka to have been elected or appointed and installed as chief of the Kusasi Area. Accra: Registry, Court of Appeal.

Pkalya, R., Adan, M and Masinde, I. (2004). Indigenous democracy; traditional conflict resolution mechanisms. Kenya: Intermediate Technology Development Group.

Rattray, R. S. (1932). Tribes of Ashanti hinterland. Oxford: Oxford University Press.

Richardson, J. M. and Sen, S. (1996). Ethnic conflict and economic development: A policy oriented analysis. America School of International Service, American University Richardson, J. M. \& Wang, J. (1993). ethnic peace accords and ethnic conflict resolution: A survey. New York: St. Martin's Press.

Tsikata, D. and Seini, W. (2004). Identities, inequalities and conflicts in Ghana. CRISE working paper. Oxford: CRISE.

UN DESA. (2001). Training of trainers workshop on conflict prevention at Swedru. United Nations. 